\title{
Intraventricular Tuberculoma with Profound Visual Loss: A Case Report and Literature Review
}

\author{
Amir Tengku-Fatishah ${ }^{1}$, Alwi Muhd Besari ${ }^{2}$, John Tharakan ${ }^{3}$, Ismail Shatriah ${ }^{4}$ \\ 1. Ophthalmology, School of Medical Sciences, Universiti Sains Malaysia, 16150 Kubang Kerian, Kelantan, USA 2. \\ Medicine, School of Medical Sciences, Universiti Sains Malaysia, 16150 Kubang Kerian, Kelantan, MYS 3. \\ Neurosciences, School of Medical Sciences, Universiti Sains Malaysia, 16150 Kubang Kerian, Kelantan, MYS 4. \\ Ophthalmology, School of Medical Sciences, Universiti Sains Malaysia, 16150 Kubang Kerian, Kelantan, MYS
}

Corresponding author: Ismail Shatriah, shatriah@usm.my

\section{Abstract}

Intracranial tuberculoma is a rare manifestation of tuberculosis involving the central nervous system. The involvement of the ventricular system is extremely uncommon. We describe a young woman with bilateral papilledema secondary to intraventricular tuberculoma with hydrocephalus. She was treated with antituberculosis therapy and intravenous dexamethasone. Her visual acuity deteriorated after one month of treatment. We provide a literature review of this uncommon ocular sequelae.

Categories: Neurology, Ophthalmology, Infectious Disease

Keywords: tuberculosis, intraventricular tuberculoma, visual loss

\section{Introduction}

Intracranial tuberculoma is a rare manifestation of tuberculosis. Recent data showed that cerebral tuberculoma accounted for $39 \%-46 \%$ of intracranial space occupying lesions [1-2]. It can spread to various portions of the brain and is commonly found in the cerebellum, basal ganglia, and cerebral hemisphere [3]. We report a rare case of intraventricular tuberculoma with hydrocephalus in a young woman who developed profound visual loss during the anti-tuberculosis treatment.

\section{Case Presentation}

A 27-year-old woman presented with a progressive painless visual loss in both eyes for one week prior to consultation. It was associated with preceding headache, nausea, and vomiting of two months duration. There was no history of prolonged fever, chronic cough, reduced weight, or loss of appetite. However, her father was treated for pulmonary tuberculosis two years ago and he had completed his anti-tuberculosis therapy.

Received 05/29/2018

Review began 06/02/2018 Review ended 06/10/2018 Published 06/14/2018

๑ Copyright 2018

Tengku-Fatishah et al. This is an open access article distributed under the terms of the Creative Commons Attribution License CC-BY 3.0., which permits unrestricted use, distribution, and reproduction in any medium, provided the original author and source are credited.
Her best corrected visual acuity was 3/60 (OD) and 4/60 (OS). The optic nerve function tests were impaired bilaterally and included light brightness, contrast sensitivity, and color vision; however, the right sight was more affected than the left. There was a relative afferent pupillary defect presence on her right eye. The confrontation test revealed generalized haziness with dense central scotoma on her bilateral vision. The anterior segment examination and intraocular pressure were essentially normal. The fundoscopy examination revealed bilateral papilledema. The optic discs were swollen and elevated with peripapillary flame-shaped hemorrhages as well as the presence of macular exudates (Figure 1). However, no sign of vitritis or panuveitis was observed.

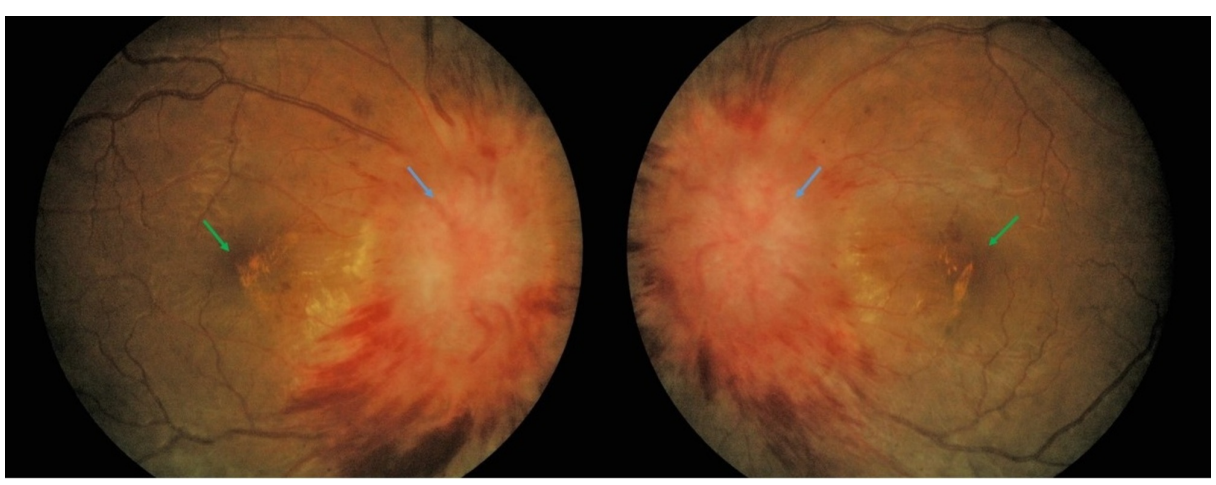

FIGURE 1: Fundus photography of bilateral eyes

Bilateral papilledema with flame-shaped hemorrhages (blue arrow) and macular exudates (green arrow) 


\section{Cureus}

On presentation, she was alert and orientated to time, place, and person. Her vital signs were stable. She was also afebrile. There were no signs of meningism or localizing signs. A respiratory examination revealed crepitation in the right lung. The other cranial nerves examinations were normal. The rest of the systemic examinations were unremarkable.

Her baseline blood investigations were unremarkable except for an increased erythrocyte sedimentation rate $(79 \mathrm{~mm} / \mathrm{h}$ ) and C-reactive protein $(23 \mathrm{mg} / \mathrm{l})$. The human immunodeficiency virus antibody test was negative. The Mantoux test was positive ( $16 \mathrm{~mm}$ area of induration). The sputum microscopic examination detected the presence of acid-fast bacilli. The chest radiograph showed cavitations at the right lower zone (Figure 2).

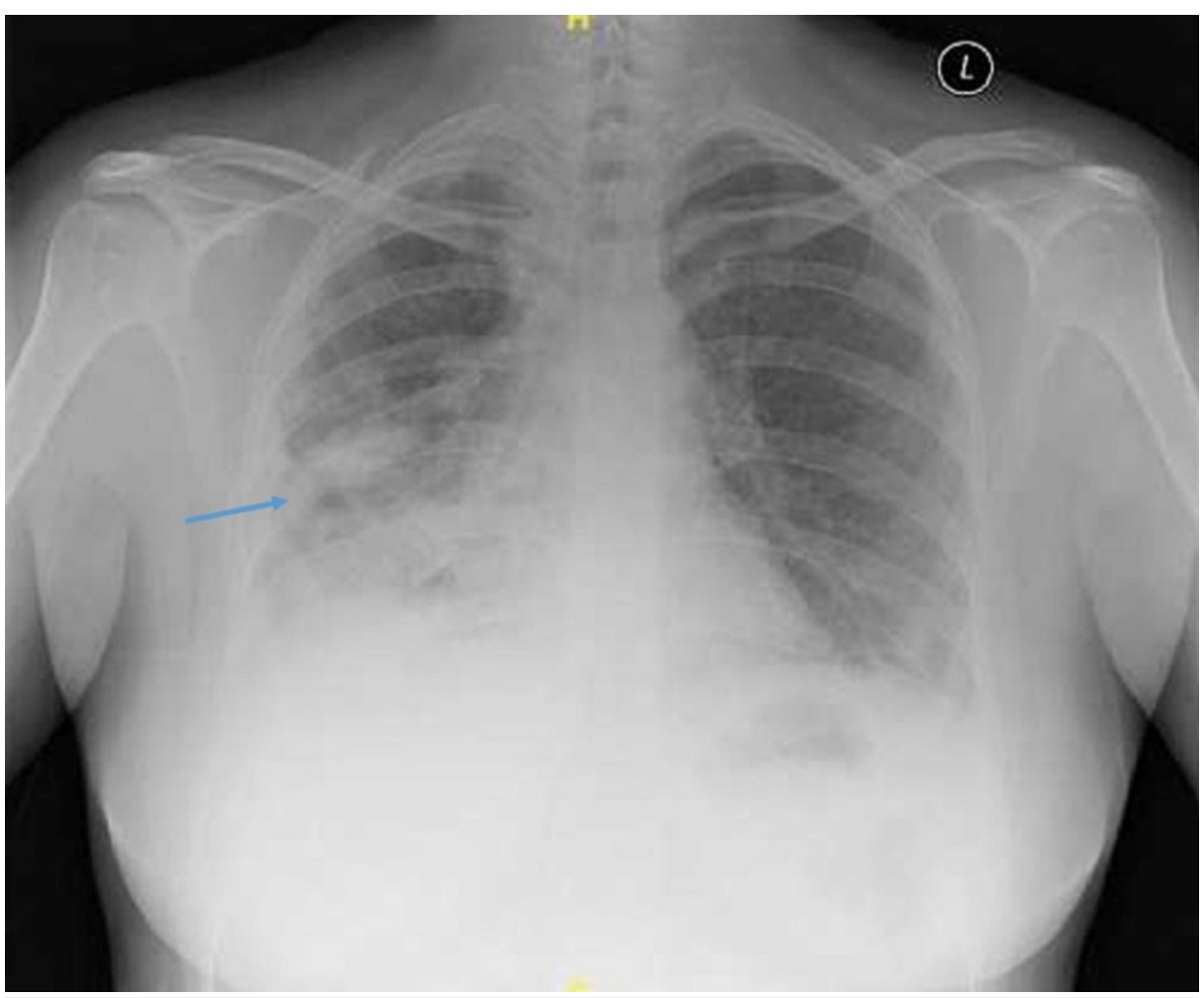

FIGURE 2: Chest radiograph

Cavitation in the right lower zone (blue arrow)

The computed tomography (CT) scan of the brain and orbit revealed the presence of multiple ringenhancing hyperdense lesions with central hypodensity and perilesional edema. The lesions were located at the anterior horn of the right lateral ventricle (Figure 3A-3B). There were also multiple small lesions at the cerebrum and cerebellum (Figure 3A).
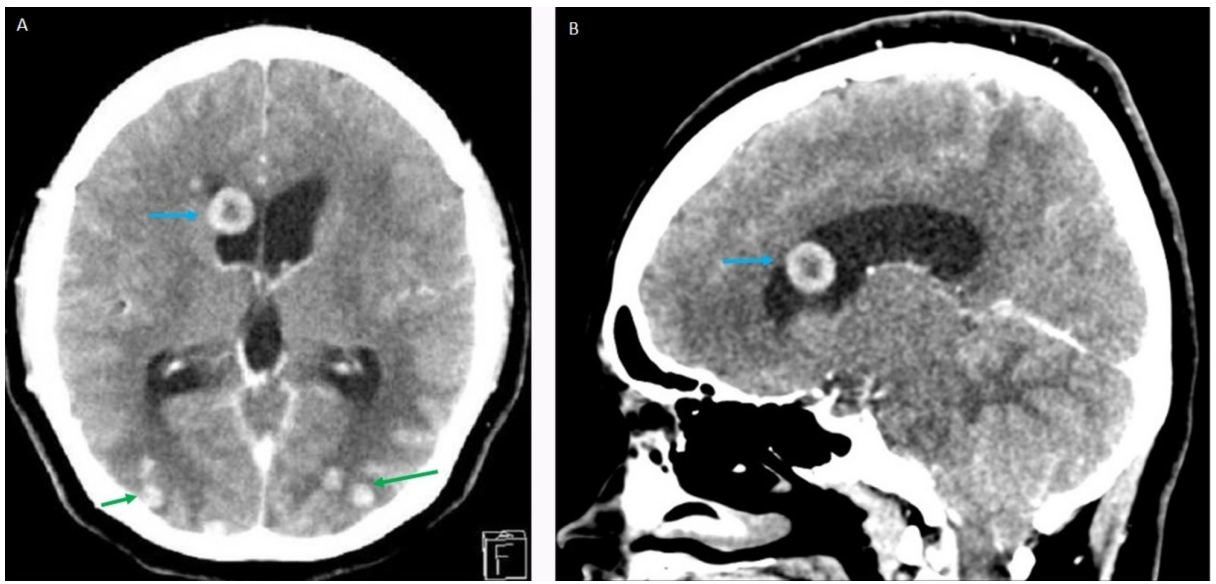

FIGURE 3: Computed tomography scan of the brain and orbit with 


\section{Cureus}

\section{contrast in the axial (3A) and sagittal cuts (3B)}

Solitary tuberculoma at the anterior horn of the right lateral ventricle (blue arrow). Multiple small parenchymatous discs were observed in the cerebrum (green arrow) with evidence of obstructive hydrocephalus

However, there was no traction over the septum pellucidum. The lateral and third ventricles were dilated on both sides. She declined further diagnostic tests, including lumbar puncture and magnetic imaging resonance (MRI) of the brain and orbit. A presumptive diagnosis of bilateral papilledema secondary to intraventricular tuberculoma with hydrocephalus was considered. However, the patient refused the ventriculoperitoneal shunt procedure.

Anti-tuberculosis therapy was commenced immediately with oral isoniazid $300 \mathrm{mg}$, oral rifampicin $600 \mathrm{mg}$, oral pyrazinamide $1500 \mathrm{mg}$, intramuscular streptomycin $1000 \mathrm{mg}$, and intravenous dexamethasone $4 \mathrm{mg}$. Her symptoms of headache, nausea, and vomiting subsided.

However, visual acuity of both eyes deteriorated progressively to non-perception of light after four weeks of treatment. She had no new emerging neurological symptoms or signs associated with the visual loss. A repeat funduscopy examination showed atrophy of the optic discs in both eyes (Figure 4).

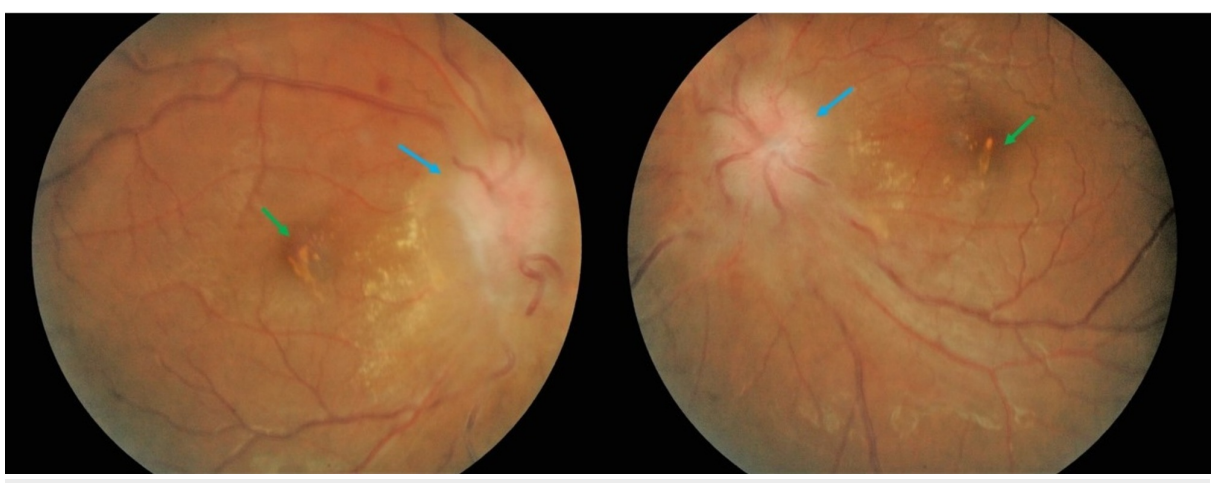

\section{FIGURE 4: Fundus photography of bilateral eyes}

Bilateral pale optic disc (blue arrow) with regressing macular exudates (green arrows) after four weeks on anti-tuberculosis therapy

We planned to extend her oral dexamethasone while continuing the same anti-tuberculosis regime. Unfortunately, the patient defaulted follow-up after one month of treatment.

\section{Discussion}

A well-developed intraventricular tuberculoma is not common in tuberculosis infections. The effective blood circulation of the ventricular system acts as a barrier to infection despite evidence of tubercles in the choroid [3-6]. Based on the PubMed search, we encountered 18 published cases of intraventricular tuberculoma from 1987 to 2018 [3-14], including the current case report in Table 1. The age ranged from two years to 62 years. There were eight males and 11 females, including our patient.

\begin{tabular}{|c|c|c|c|c|c|c|c|c|}
\hline Author & Year & Sex/Age & Tuberculoma Location & Initial VA & Ocular Finding & Treatment & Follow-Up & Final Outcome \\
\hline \multirow[b]{3}{*}{$\begin{array}{l}\text { Berthier, et al. } \\
\text { [3] }\end{array}$} & \multirow[b]{3}{*}{1987} & $M / 4$ & $\begin{array}{l}\text { Left lateral ventricle with traction of the septum } \\
\text { pellucidum. Presence of asymmetrical hydrocephalus }\end{array}$ & $\begin{array}{l}\text { Not } \\
\text { available }\end{array}$ & $\begin{array}{l}\text { Right } \\
\text { oculomotor nerve } \\
\text { palsy. No } \\
\text { papilledema }\end{array}$ & Anti-tuberculosis & 3 weeks & Good recovery \\
\hline & & $\mathrm{F} / 5$ & Right lateral ventricle and right capsular region & $\begin{array}{l}\text { Not } \\
\text { available }\end{array}$ & Not available & Anti-tuberculosis & 3 months & Good recovery \\
\hline & & $M / 4$ & $\begin{array}{l}\text { Right lateral ventricle with traction of the septum } \\
\text { pellucidum. Another lesion seen in the cerebral }\end{array}$ & $\begin{array}{l}\text { Not } \\
\text { available }\end{array}$ & $\begin{array}{l}\text { Bilateral } \\
\text { papilledema with }\end{array}$ & $\begin{array}{l}\text { Anti-tuberculosis, } \\
\text { Dexamethasone, VP }\end{array}$ & Defaulted & $\begin{array}{l}\text { After the VP shunt, } \\
\text { the patient } \\
\text { neurologically }\end{array}$ \\
\hline
\end{tabular}




\section{Cureus}

\begin{tabular}{|c|c|c|c|c|c|c|c|c|}
\hline & & & hemisphere. Presence of asymmetrical hydrocephalus & & choroiditis & shunt & & $\begin{array}{l}\text { improved. However, } \\
\text { he defaulted follow-up }\end{array}$ \\
\hline & & $F / 2$ & $\begin{array}{l}\text { Left lateral ventricle, thalamus, cerebral, cerebellar, } \\
\text { basal ganglia, and brainstem. Presence of } \\
\text { hydrocephalus }\end{array}$ & $\begin{array}{l}\text { Not } \\
\text { available }\end{array}$ & No papilledema & Anti-tuberculosis & 12 months & Good recovery \\
\hline $\begin{array}{l}\text { Vajramani, } \\
\text { et al. [4] }\end{array}$ & 1999 & $F / 26$ & Right lateral ventricle. Presence of hydrocephalus & $\begin{array}{l}\text { Not } \\
\text { available }\end{array}$ & $\begin{array}{l}\text { Bilateral sixth } \\
\text { cranial nerve } \\
\text { palsy. No } \\
\text { papilledema }\end{array}$ & $\begin{array}{l}\text { Anti- } \\
\text { tuberculosis, Surgical } \\
\text { excision, VP shunt }\end{array}$ & 14 months & Good recovery \\
\hline Desai, et al. [5] & 2002 & $F / 38$ & $\begin{array}{l}\text { Within septum pellucidum. Presence of moderate } \\
\text { obstructive hydrocephalus }\end{array}$ & $\begin{array}{l}\text { Not } \\
\text { available }\end{array}$ & No papilledema & $\begin{array}{l}\text { Anti-tuberculosis, } \\
\text { Surgical excision }\end{array}$ & 9 months & Good recovery \\
\hline Hsu, et al. [6] & 2004 & $\mathrm{~F} / 19$ & Right lateral ventricle. Presence of hydrocephalus & $\begin{array}{l}\text { Not } \\
\text { available }\end{array}$ & Mild papilledema & $\begin{array}{l}\text { Anti-tuberculosis, } \\
\text { Surgical excision, VP } \\
\text { shunt }\end{array}$ & 12 months & Good recovery \\
\hline $\begin{array}{l}\text { Sonmez, et } \\
\text { al. [7] }\end{array}$ & 2008 & $\mathrm{M} / 22$ & $\begin{array}{l}\text { Right lateral ventricle. Presence of asymmetrical } \\
\text { hydrocephalus }\end{array}$ & $\begin{array}{l}\text { Not } \\
\text { available }\end{array}$ & Not available & $\begin{array}{l}\text { Surgical excision, Anti- } \\
\text { tuberculosis }\end{array}$ & $\begin{array}{l}\text { Not } \\
\text { available }\end{array}$ & Not available \\
\hline N'da, et al. [8] & 2013 & $F / 10$ & Third ventricle. Presence of obstructive hydrocephalus & $\begin{array}{l}\text { Bilateral } \\
\text { VA loss }\end{array}$ & Not available & $\begin{array}{l}\text { Surgical excision, Anti- } \\
\text { tuberculosis }\end{array}$ & 6 months & $\begin{array}{l}\text { Good recovery, } \\
\text { however, final VA } \\
\text { outcome was not } \\
\text { mentioned }\end{array}$ \\
\hline $\begin{array}{l}\text { Coulibaly, } \\
\text { et al. [9] }\end{array}$ & 2013 & $M / 26$ & $\begin{array}{l}\text { Right lateral ventricle. Presence of asymmetrical } \\
\text { hydrocephalus }\end{array}$ & OU $4 / 60$ & Not available & $\begin{array}{l}\text { Surgical excision, External } \\
\text { ventricular drainage, Anti- } \\
\text { tuberculosis, Steroid }\end{array}$ & 3 months & $\begin{array}{l}\text { Total disappearance of } \\
\text { the lesion. Final VA } \\
\text { outcome was not } \\
\text { mentioned }\end{array}$ \\
\hline $\begin{array}{l}\text { Udayakumaran, } \\
\text { et al. [10] }\end{array}$ & 2014 & $\mathrm{~F} / 27$ & $\begin{array}{l}\text { Third ventricle and thalamus. Presence of obstructive } \\
\text { hydrocephalus }\end{array}$ & $\begin{array}{l}\text { Not } \\
\text { available }\end{array}$ & Not available & $\begin{array}{l}\text { Anti- } \\
\text { tuberculosis, Ofloxacin, } \\
\text { Ethionamide, Endoscopic } \\
\text { third ventriculostomy }\end{array}$ & 12 months & Good recovery \\
\hline $\begin{array}{l}\text { Sachdeva, } \\
\text { et al. [11] }\end{array}$ & 2017 & $\mathrm{M} / 7$ & oramen of Monro & $\begin{array}{l}\text { Not } \\
\text { available }\end{array}$ & $\begin{array}{l}\text { Bilateral } \\
\text { papilledema }\end{array}$ & $\begin{array}{l}\text { Surgical excision, Anti- } \\
\text { tuberculosis }\end{array}$ & 15 months & Good recovery \\
\hline $\begin{array}{l}\text { Sharma, } \\
\text { et al.[12] }\end{array}$ & 2017 & $\mathrm{~F} / 21$ & Third ventricle with obstructive hydrocephalus & $\begin{array}{l}\text { Not } \\
\text { available }\end{array}$ & $\begin{array}{l}\text { Bilateral } \\
\text { papilledema }\end{array}$ & $\begin{array}{l}\text { VP shunt, Surgical } \\
\text { excision, Anti- } \\
\text { tuberculosis }\end{array}$ & 1 month & Good recovery \\
\hline $\begin{array}{l}\text { Sadashiva, } \\
\text { et al. [13] }\end{array}$ & 2017 & $M / 33$ & Left lateral ventricle with obstructive hydrocephalus & $\begin{array}{l}\text { Not } \\
\text { available }\end{array}$ & Not available & $\begin{array}{l}\text { Anti- } \\
\text { tuberculosis, Endoscopic } \\
\text { biopsy, VP shunt }\end{array}$ & 16 months & Good recovery \\
\hline \multirow{4}{*}{ Li, et al. [14] } & \multirow{4}{*}{2017} & $F / 62$ & Fourth ventricle & $\begin{array}{l}\text { Not } \\
\text { available }\end{array}$ & Not available & $\begin{array}{l}\text { Intrathecal isoniazid, } \\
\text { Dexamethasone, Anti- } \\
\text { tuberculosis }\end{array}$ & 9 months & $\begin{array}{l}\text { Tuberculoma size } \\
\text { decreased }\end{array}$ \\
\hline & & $F / 31$ & ourth ventricle and right lateral ventricle & $\begin{array}{l}\text { Not } \\
\text { available }\end{array}$ & Not available & $\begin{array}{l}\text { Intrathecal isoniazid, } \\
\text { Dexamethasone, Anti- } \\
\text { tuberculosis }\end{array}$ & 3.5 months & $\begin{array}{l}\text { Tuberculoma size } \\
\text { decreased }\end{array}$ \\
\hline & & $\mathrm{M} / 23$ & Right lateral ventricle & $\begin{array}{l}\text { Not } \\
\text { available }\end{array}$ & Not available & $\begin{array}{l}\text { Intrathecal isoniazid, } \\
\text { Dexamethasone, Anti- } \\
\text { tuberculosis }\end{array}$ & 7 months & $\begin{array}{l}\text { Disappearance of } \\
\text { tuberculoma }\end{array}$ \\
\hline & & $\mathrm{M} / 47$ & Right lateral ventricle. Presence of hydrocephalus & $\begin{array}{l}\text { Not } \\
\text { available }\end{array}$ & Not available & $\begin{array}{l}\text { Intrathecal isoniazid, } \\
\text { Dexamethasone, Anti- } \\
\text { tuberculosis }\end{array}$ & 15 months & $\begin{array}{l}\text { Disappearance of } \\
\text { tuberculoma }\end{array}$ \\
\hline Present study & 2018 & $F / 27$ & $\begin{array}{l}\text { Right lateral ventricle, cerebral, and cerebellum. } \\
\text { Presence of obstructive hydrocephalus }\end{array}$ & $\begin{array}{l}3 / 60 \text { OD } \\
4 / 60 \text { OS }\end{array}$ & $\begin{array}{l}\text { Bilateral } \\
\text { papilledema }\end{array}$ & $\begin{array}{l}\text { Anti-tuberculosis } \\
\text { Dexamethasone }\end{array}$ & 1 month & $\begin{array}{l}\text { Bilaterally, no } \\
\text { perception of light. } \\
\text { Patient defaulted } \\
\text { follow-up }\end{array}$ \\
\hline
\end{tabular}


TABLE 1: Published cases of interventricular tuberculoma from 1987 to 2018

VA, visual acuity; F, female; M, male; VP, ventriculoperitoneal

The hematogenous spread of Mycobacterium tuberculosis through the choroidal plexus or ependyma is the common route of tubercle bacilli entry [3,5-7]. Berthier et al. reported that three of their patients had a lateral ventricle tuberculoma without choroidal plexus involvement [3]. These findings were similar to our patient who developed a right lateral ventricle tuberculoma without signs of choroidal plexus involvement. The tuberculoma in these patients probably arose from the subependymal tubercle.

Our patient developed a deterioration of visual acuity after four weeks of anti-tuberculosis therapy commencement. We postulate that this could be due to a paradoxical expansion of tuberculoma and the worsening of the pre-existing hydrocephalus. The paradoxical phenomenon has been described in multiple works of literature [14-19]. It is described as an excessive immune response by the host cell to the mycobacterial antigen that causes the expansion of the initial lesion or the growing of a new tuberculoma during the anti-tuberculosis therapy [17].

Another possible mechanism is due to poor drug penetration into the ventricular system. Udayakumaran et al. had performed an external third ventriculostomy in a case with a third intraventricular tuberculoma and obstructive hydrocephalus [10]. Despite multiple cerebral spinal fluid redirection procedures that had been performed along with the anti-tuberculosis regime, the tuberculoma was still being intractable. Thus, endoscopic third ventriculostomy was performed to excise the lesion and further cleared the cerebrospinal fluid route simultaneously [10]. Li and colleagues demonstrated a favorable outcome with the intrathecal isoniazid therapy [14].

A variety of treatment modalities had been attempted, as shown in Table 1 . Five authors opted for prior surgical excision especially when the diagnosis was doubted [7-9,11-12]. This was due to the rarity of the tumor location or the absence of the systemic manifestation of tuberculosis infection. The lesion may also be imitating malignancy, as there were no specific clinical signs suggesting intraventricular tuberculoma. These patients were started on anti-tuberculosis treatment after a histopathology study confirmed tuberculoma [7$9,11]$.

Most of the published cases presented with features of hydrocephalus [3-10,12-14]. Six of these patients underwent cerebral spinal fluid redirection procedures, which included a ventriculoperitoneal shunt and external ventricular drainage [3-4,6,9,13-14]. Our patient was treated conservatively with an antituberculosis regime and intravenous dexamethasone because she declined a ventriculoperitoneal shunt and further surgical intervention.

\section{Conclusions}

Progressive visual loss during the treatment of an intraventricular tuberculoma with hydrocephalus is a challenging clinical scenario. Apart from poor drug penetration into the cerebrospinal fluid, the paradoxical reaction may be attributed to the recalcitrant nature of the disease. A standard guideline on the treatment regime is mandatory. This is very essential to prevent permanent visual loss and further neurological disability.

\section{Additional Information \\ Disclosures}

Human subjects: Consent was obtained by all participants in this study. Conflicts of interest: In compliance with the ICMJE uniform disclosure form, all authors declare the following: Payment/services info: All authors have declared that no financial support was received from any organization for the submitted work. Financial relationships: All authors have declared that they have no financial relationships at present or within the previous three years with any organizations that might have an interest in the submitted work. Other relationships: All authors have declared that there are no other relationships or activities that could appear to have influenced the submitted work.

\section{References}

1. Maheshwari V, Srivastava VK, Prasad S, Alam K: Tuberculoma-a significant diagnostic entity in brain biopsies of intracranial space occupying lesions in children. J Trop Pediatr. 2002, 48:242-244. 10.1093/tropej/48.4.242

2. Anuradha HK, Garg RK, Sinha MK, Agarwal A, Verma R, Singh MK, Shukla R: Intracranial tuberculomas in patients with tuberculous meningitis: predictors and prognostic significance. Int J Tuberc Lung Dis. 2011, 15:234-239.

3. Berthier M, Sierra J, Leiguarda R: Intraventricular tuberculoma: report of four cases in children . 
Neuroradiology. 1987, 29:163-167. 10.1007/BF00327542

4. Vajramani GV, Devi BI, Hegde T, Santosh V, Khanna N, Vasudev MK: Intraventricular tuberculous abscess. A case report. Neurol India. 1999, 47:327-329.

5. Desai K, Nadkarni T, Bhatjiwale M, Goel A: Intraventricular tuberculomas. Neurol Med Chir (Tokyo). 2002, 42:501-503. 10.2176/nmc.42.501

6. Hsu PW, Lin TK, Chang CN: Solitary intraventricular tuberculoma in adults. Acta Neurochir. 2004, 146:1151-1153. 10.1007/s00701-004-0291-7

7. Sonmez G, Ozturk E, Mutlu H, et al.: An unusual intraventricular lesion: tuberculoma. J Neuroradiol. 2008, 35:63-64. 10.1016/j.neurad.2007.06.008

8. N'da HA, Haidara A, Drogba L, Derou LK, Yao SK, Zéze V: A rare third ventricle solitary tuberculoma . Pan Afr Med J. 2013, 16:5. 10.11604/pamj.2013.16.5.2815

9. Coulibaly 0, Diawara S, Quénum K, et al.: Intraventricular tuberculoma: a case report. CRCM. 2013, 2:81-84. 10.4236/crcm.2013.21022

10. Udayakumaran S, Nair P, Kumar A, Panikar D: Role of endoscopy in recalcitrant intraventricular tuberculoma - innovative novel treatment adjunct. Br J Neurosurg. 2014, 15:1-5. 10.3109/02688697.2014.957154

11. Sachdeva D, Bishnoi I, Jagetia A, Rathore L, Agarwal A, Batra V, Kaur A: Intraventricular tuberculoma in a child: a rare location. Pediatr Neurosurg. 2017, 52:93-97. 10.1159/000450756

12. Sharma GR, Kaushal P, Vaidya B, Kumar P: Third ventricular tuberculoma mimicking as a tumor: report of a very rare case. Asian J Neurosurg. 2017, 12:58-61. 10.4103/1793-5482.145061

13. Sadashiva N, Nandeesh BN, Shukla D, Devi BI: Case reports. Choroid plexus tuberculoma. Diagnosis, management and role of endoscopy. Neurosciences (Riyadh). 2017, 22:216-219. 10.17712/nsj.2017.3.20160465

14. Li D, Lv P, Lv Y, Ma D, Yang J: Magnetic resonance imaging characteristics and treatment aspects of ventricular tuberculosis in adult patients. Acta Radiol. 2017, 58:91-97. 10.1177/0284185116633913

15. Hejazi N, Hassler W: Multiple intracranial tuberculomas with atypical response to tuberculostatic chemotherapy: literature review and a case report. Infection. 1997, 25:233-239. 10.1007/BF01713151

16. Kalkan A, Serhatlioglu S, Ozden M, Denk A, Demirdag K, Yilmaz T, Kilic SS: Paradoxically developed optochiasmatic tuberculoma and tuberculous lymphadenitis: a case report with 18 month follow up by MRI. South Med J. 2006, 99:388-392. 10.1097/01.smj.0000209091.57281.23

17. Monga P, Dhaliwal U: Paradoxical reaction in tubercular meningitis resulting in involvement of optic radiation. Indian J Ophthalmol. 2009, 57:139-141. 10.4103/0301-4738.45504

18. Sinha MK, Garg RK, Anuradha HK, Agarwal A, Parihar A, Mandhani PA: Paradoxical vision loss associated with optochiasmatic tuberculoma in tuberculous meningitis: a report of 8 patients. J Infect. 2010, 60:458466. 10.1016/j.jinf.2010.03.013

19. Garg RK, Malhotra HS, Kumar N: Paradoxical reaction in HIV negative tuberculous meningitis . J Neurol Sci. 2014, 340:26-36. 10.1016/j.jns.2014.03.025 